STARKEY, H. (2008) Diversity and Citizenship in the Curriculum. London

Review of Education, 6, 3-8.

\title{
Diversity and Citizenship in the Curriculum
}

\section{Hugh Starkey}

\section{University of London, Institute of Education}

This article reflects and comments on the keynote speeches given by Sir Keith Ajegbo and Professor Audrey Osler at the start of the international conference Education for Democratic Citizenship: multiculturalism and national identity organised by the International Centre for Education for Democratic Citizenship (ICEDC) on 13 July 2007. The papers in this special issue of the London Review of Education have been selected from the 43 contributions delivered at the conference. Audrey Osler's paper in this collection engages directly with the Diversity and Citizenship curriculum review (Ajegbo, 2007). I will therefore focus in this article on the broader, more contextual issues that she raised in her keynote.

Creative ambiguity is a diplomatic term that, I would argue, has become a characteristically British approach to attempting to achieve a political consensus for action. Unlike the French expectation of Cartesian rationality with respect to the application of principles, the British system of governance barely allows core principles to be derived or defined. The unwritten British constitution relies on a system of 'hidden wiring' (Hennessy, 1995) leaving much space for interpretation and also for implicit understandings. To evoke a long tradition of doing things this way is a powerfully authoritative argument in many British contexts.

Implicitness and lack of transparency is, of course, profoundly undemocratic. Implicit understandings of the way decisions are made exclude those who have not been socialised into the powerful group of those who do know and understand the system. Women in Britain have been less involved in political decision making (Lister, 1997) and their representation remains well below the expected level (Singh, 2007). Black and minority ethnic groups are also woefully under-represented in political processes. As Audrey Osler reminded us, quoting James Banks, 'a citizen's racial, cultural, language and religious characteristics often significantly influence whether she is viewed as a citizen within her society'(2004:5).

The Crick report directly and unambiguously addresses the knowledge, skills, values and dispositions required by citizens living together in the UK. In proposing a detailed but concise programme of study for all young people within the school education system, it makes explicit the expectations of citizenship. These include, notably: 'concern for the common good'; belief in human dignity and equality; commitment to equal opportunities and gender equality; concern for human rights' (Crick, 1998: 44). By spelling out these 
normative expectations, teachers of citizenship are making a direct contribution to democracy by de-mystifying the implicit meanings of the concept.

Active citizenship, one of the prime goals of citizenship education in this newly established British (or rather, English) tradition, is therefore a disposition to address issues of exclusion, discrimination and other practices and procedures that have tended to perpetuate the undemocratic tendencies of British society and its institutions. This disposition may be powerfully supported by the law, which makes the obligations of citizens explicit. So, for example, the Race Relations (Amendment) Act 2000 obliges all public bodies including schools to promote race equality. The Education and Inspections Act 2006 introduced a duty on the governing bodies of maintained schools to promote community cohesion.

The period between the publication of the Crick report and the formal introduction of citizenship into the school curriculum was notable for significant policy initiatives in the areas of race equality and security. The Stephen Lawrence Inquiry (Macpherson, 1999) recommended a greater role for citizenship education in combating racism. The recommendation was accepted in principle by the DfEE, but initially stubbornly opposed by the inspection service OFSTED. It was this refusal that caused the resignation of the chief inspector of schools, following his appearance before the Education and Employment select committee (Osler \& Morrison, 2000). The al-Qaeda attacks on the World Trade Center and the Pentagon on 11 September 2001 led to the raising of security to the top of the political agenda. This found legislative expression in the Nationality, Asylum and Immigration Act [2002] and the Immigration, Asylum and Nationality Act [2006] that followed the July 2005 London suicide bombings.

Citizenship education was seen by successive governments and ministers as a very significant response to both the race equality and the security agendas. Indeed between 1997 and 2005 both agendas were intimately linked since they were the responsibility of the same ministry, namely the Home Office. However, the programme of study for citizenship, drawn up by the Qualifications and Curriculum Authority (QCA) was derived closely from the recommendations of the Crick report and this did not recognise the importance of these agendas. This was perhaps excusable in the case of a post $9 / 11$ security agenda, since the report was published three years before. However, Crick's Advisory Group could have been expected to recognise that citizenship education in England needed to be contextualised within a multicultural society and a globalised world.

Recent research reveals that the some members of the Advisory Group felt multiculturalism was 'overdone' in schools (Pykett, 2007:311). The composition of the Group was defined by one member as those 'likely to contribute to a sensible discussion' (Kiwan, 2007: 36). This implicit consensus about the limits of debate was a serious weakness of the Group as Bernard Crick acknowledged (Kiwan, 2007). Many members of the Group were reluctant to engage with issues of equalities, feeling that 'the issue of diversity was not something of relevance to them' (Kiwan, 2007: 35). To address diversity would have taken the Group beyond its comfort zone and into the political 
arena. The prominent discourse of members of the Group has been summarised as: 'there was absolutely nothing political about Citizenship Education' (Pykett, 2007: 307).

It is not surprising, therefore, that the academic debate on the role of citizenship education at the time of its formal inception in England included analyses of the Crick report that highlighted its essentially colour-blind approach (Osler, 2000; Osler \& Starkey, 2001). Colour-blindness is 'an obstinate refusal to consider ethnic diversity despite a wealth of evidence that minorities are not sharing equally' (Gillborn, 2001: 18).

The lacuna became more apparent with the publication of the Parekh report on The Future of Multiethnic Britain (Parekh, 2000). This early contribution to debates on Britishness also made recommendations about citizenship education, namely that in the interests of building a 'community of communities' the programme of study should include specifically: 'human rights principles; stress on skills of deliberation, advocacy and campaigning; understanding of equality legislation; and opposition to racist beliefs and behaviour' (Parekh, 2000: 149).

Subsequent calls for 'the re-visioning of citizenship education' to incorporate the insights of the Parekh report (Olssen, 2004) and for 'changing citizenship' so as to reformulate it as 'democracy and inclusion in education' (Osler \& Starkey, 2005) and for 'inclusive citizenship' (Kiwan, 2007) provided an academic rationale for reviewing the programme of study for citizenship. By late 2006 this coincided with a government agenda on security that paved the way for a review of citizenship education intended to address the missing dimensions of unity and diversity within the national democracy.

Gordon Brown and Tony Blair both made keynote speeches emphasising the need for greater social integration and both attributing a key role to citizenship education. For Blair the emphasis should be on human rights:

we have a very established set of rights that constitute our citizenship. We should not be shy to teach them. That is why citizenship became part of the statutory national curriculum in secondary schools in 2002 (Blair, 2006).

Brown takes a more historical perspective I believe strongly in the case for citizenship lessons in our schools but for citizenship to matter more, these changes to the curriculum must be part of a far more extensive debate - a debate that, like the wide ranging debate we see in America about what it is to be an American and what America stands for, includes our culture and history as well as our constitution and laws (Brown, 2004).

It is the latter perspective that provided the terms of reference for the curriculum review commissioned in 2006 by the QCA and chaired by Sir Keith Ajegbo. Its mandate was to:

- Review the teaching specifically of ethnic, religious and cultural diversity across the curriculum to age 19

- In relation to Citizenship, explore particularly whether or not 'modern British social and cultural history' should be a fourth pillar of the Citizenship curriculum (Ajegbo, 2007: 14). 
Perhaps surprisingly Sir Keith and the review team did not question whether ethnic, religious and cultural diversity is something that lends itself to being taught, as opposed to something that people can learn about. In his keynote, he suggested that the context was indeed a concern with national security, though he expressed this in a very British way, assuming common references and understandings in his audience. 'We were asked to do this following events that seemed to threaten community cohesion and asked questions about a sense of national identity'.

In her contribution Audrey Osler was able to make explicit the reference to 'events'. She noted that a DfES press release announcing the publication of the review stated that: "the report was commissioned after concern about growing extremism and division in society after the London terrorist bombings'. Thus, as Sir Keith interpreted his mandate: 'citizenship education was asked to respond to a political concern about young people with the hope that it had the power to change attitudes, perceptions and behaviours'.

As educators we might ask whether the political demands placed on citizenship education, can be fulfilled in the terms in which they are formulated, or whether we need to propose alternative approaches. The different perspectives of Sir Keith and Professor Osler precisely illustrate these two positions. For the former, the terms of reference of the review team were accepted as a challenge. For Audrey Osler on the other hand, addressing diversity in the curriculum means confronting the inadequacies of British democracy and reasserting social justice, a sense of shared humanity and a commitment to human rights.

Sir Keith is profoundly committed to citizenship education. His leadership on this issue at Deptford Green School where he was Head has been an inspiration. In his speech he noted further examples of where citizenship education is high on government agendas. The report of the Commission on Integration and Cohesion (Singh, 2007) fully supports the conclusions of the Ajegbo review. The Governance of Britain Green Paper (Secretary of State for Justice, 2007) announced that a new Youth Citizenship Commission would examine citizenship education and encourage a debate on citizenship and on national values. He also regretted that the key DCSF policies of Every Child Matters, personalised learning and the duty on governing bodies for schools to promote community cohesion were not more explicitly associated with citizenship education.

In an earlier public speech (Ajegbo, 2007b) Sir Keith noted the impact on the review team of a meeting with Professor Bhikhu Parekh at which he advised them that it was likely to be unhelpful to discuss Britishness in terms of national values, but rather to recognise that the British State has committed itself at various time to certain basic principles made explicit in international treaties and instruments. For example the principle of equality of dignity and equality of rights, articulated in the Universal Declaration of Human Rights (UDHR) is recognised as fundamental by the British State, but respect for dignity and equality are not specifically British values. Sir Keith also attributed to his meeting with Professor Parekh an understanding that a monolithic personal national identity is no longer a prevalent model, given that people are increasingly aware of their multiple identities. 
It is possible that the meeting with Professor Parekh came too late to influence the main thrust of the case put forward in the curriculum review. Whilst Audrey Osler noted that the review acknowledges the multiple identities of learners and recognises diversity as something relevant to all, not just to minorities, she also noted that the review essentially remains within a nationalist paradigm for citizenship. She challenged this approach, which is that implicit in the political steer given to the review team. Instead, she proposed a cosmopolitan perspective, based on citizens understanding that they have a place in a world community (what the Universal Declaration of Human Rights calls 'the human family') based on common human values (Anderson-Gold, 2001). The common human values also find expression in the UDHR.

Education for cosmopolitan citizenship is a concept that has been developed by Osler and Starkey $(2002,2003,2005)$ in the context of their research with young people in Leicester and in South Africa. Professor Osler quoted from the report of her European research project on global education, which suggests that:

Education for cosmopolitan citizenship ...implies a broader understanding of national identity; it requires recognition that British identity, for example, may be experienced differently by different people (Osler and Vincent, 2002: 124).

The fact that is not reasonable or even feasible to propose, let alone impose, a definition of Britishness or British identity, does not mean that it is not possible to discuss and even promote patriotism. Professor Osler quoted approvingly the Canadian philosopher Charles Taylor who argues that:

I am saying that we have no choice but to be cosmopolitans and patriots, which means to fight for the kind of patriotism that is open to universal solidarities against other, more closed kinds (1996:121).

It may be that implicitness has been a characteristic of much of British society and governance. It would appear that there is a recognition by many political leaders that key principles and values that are crucial in holding any society together need to be articulated. The explicit commitments to democracy and human rights that underpin the European Union and the Council of Europe should be the core of any transmission model of citizenship education. Diversity is essential to democracy. It is impossible to envisage a democratic system where everyone simply shares the same opinion and thinks alike. In Walter Parker's elegant formula: 'diversity figures as the most central deliberative asset' (2004:453).

In implementing the recommendations of the Ajegbo review, which she welcomes, Audrey Osler proposes that educators also pay attention to the very explicit principles and concepts proposed by the international consensus panel convened by the Center for Multicultural Education at the University of Washington, Seattle (Banks et al., 2005). In so doing, it may be possible to help heads and teachers to find the inclusion of diversity in the curriculum less worrying and controversial. By being quite explicit about the principles, concepts and values that underpin citizenship education in the multicultural as 
well as multinational state that is the UK, it may be possible to dispel some of the mistrust and disaffection that undermines democracy and community cohesion. 
References

Advisory Group on Citizenship. 1998. Education for citizenship and the teaching of democracy in schools. The crick report. London: Qualifications and Curriculum Authority. http://www.qca.org.uk/downloads/crick_report_1998.pdf

Ajegbo, K. 2007. Curriculum review diversity and citizenship. London: Department for Education and Skills.

---. 2007. Diversity and citizenship: The impact of schools. London: Keynote speech for Children's Services Network conference 13 May 2007.

Anderson-Gold, S. 2001. Cosmopolitanism and human rights. Cardiff: University of Wales Press.

Banks, J.A. ed. 2004. Diversity and citizenship education: Global perspectives. San Francisco, CA: Jossey-Bass.

Banks, J.A., C.A.M. Banks, C.E. Cortes, C. Hahn, M. Merryfield, K.A. Moodley, S. Murphy-Shigematsu, A. Osler, C. Park and W.C. Parker. 2005. Democracy and diversity: Principles and concepts for educating citizens in a global age. Seattle, WA: Center for Multicultural Education, University of Washington.

Blair, T. 2006. The duty to integrate: Shared british values. Speech delivered 8 December 10 Downing Street: http://www.number10.gov.uk/output/Page10563.asp.

Brown, G. July 7 2004. British council annual lecture. London: http://www.hmtreasury.gov.uk/newsroom_and_speeches/press/2004/press_63_04.cfm.

Crick, B. 1998. Education for citizenship and the teaching of democracy in schools: Final report of the advisory group on citizenship. London: Qualifications and Curriculum Authority. http://www.qca.org.uk/downloads/crick_report_1998.pdf

Gillborn, D. 2001. Racism, policy and the (mis)education of black children. In Educating our black children: New directions and radical approaches 13-27. London: Routledge-Falmer.

Hennessy, P. 1995. The hidden wiring: Unearthing the british constitution. London: Victor Gollancz.

Kiwan, D. 2007. Education for inclusive citizenship London: Routledge.

Lister, R. 1997. Citizenship: Feminist perspectives. London: Macmillan.

Macpherson, W. 1999. The stephen lawrence inquiry. London: The Stationery Office.

Olssen, M. 2004. From the crick report to the parekh report: Multiculturalism, cultural difference, and democracy - the re-visioning of citizenship education. In British Journal of Sociology of Education, 179-92.

Osler, A. 2000. The crick report: Difference, equality and racial justice. In Curriculum Journal, 25-37.

Osler, A. and M. Morrison. 2000. Inspecting schools for racial equality: Ofsted's strengths and weaknesses. Stoke-on-Trent: Trentham, for the Commission for Racial Equality.

Osler, A. and H. Starkey. 2001. Citizenship education and national identities in france and england: Inclusive or exclusive? In Oxford Review of Education, 287-305.

---. 2002. Learning to live together: Young people as cosmopolitan citizens. In $L a$ problématique du vivre ensemble et les curricula. / Learning to live together and curricular contents. Geneva: SRED. 
---. 2003. Learning for cosmopolitan citizenship: Theoretical debates and young people's experiences. In Educational Review, 243-54.

---. 2005. Changing citizenship: Democracy and inclusion in education. Maidenhead: Open University Press.

Osler, A. and K. Vincent. 2002. Citizenship and the challenge of global education. Stoke on Trent: Trentham.

Parekh, B. 2000. The future of multi-ethnic britain. London: The Runnymede Trust.

Parker, W. 2004. Diversity, globalization, and democratic education: Curriculum possibilities. In Diversity and citizenship education: Global perspectives, 433-58. San Francisco: Jossey-Bass.

Pykett, J. 2007. Making citizens governable? The crick report as governmental technology. In Journal of Education Policy, 301-19.

Secretary of State for Justice. 2007. The governance of britain (green paper). London: Ministry of Justice.

Singh, D. 2007. Our shared future: Final report of the commission on integration and cohesionLondon: Commission on Integration and Cohesion.

Taylor, C. 1996. Why democracy needs patriotism. In For love of country: Debating the limits of patriotism. Boston MA: Beacon Press. 